\title{
Studies on Different Crop Establishment Techniques and Nitrogen Management on Basmati Rice Variety (Pusa basmati 1509)
}

\author{
Nurina Shahni ${ }^{1 *}$, K. Nandini Devi ${ }^{1}$, Mary Chongtham ${ }^{1}$, \\ Herojit Singh Athokpam ${ }^{2}$ and N. Gopimohan Singh ${ }^{3}$
}

${ }^{1}$ Department of Agronomy, College of Agriculture, CAU, Imphal - 795004, Manipur, India

${ }^{2}$ Department of Soil Science and Agricultural Chemistry, College of Agriculture, CAU, Imphal - 795004, Manipur, India

${ }^{3}$ Department of Basic Science, College of Agriculture, CAU, Imphal - 795004, Manipur, India

*Corresponding author:

\section{A B S T R A C T}

\begin{tabular}{|l|}
\hline Ke y w or d s \\
Establishment \\
techniques, \\
Integrated nitrogen \\
management, \\
Farmyard manure, \\
Broadcasting, \\
Transplanting \\
\hline Article Info \\
\hline $\begin{array}{l}\text { Accepted: } \\
\text { 17 May } 2019 \\
\text { Available Online: } \\
\text { 10 June } 2019\end{array}$ \\
\hline \hline
\end{tabular}

\section{Introduction}

Rice is a staple food for more than $50 \%$ of the world population. The leading aromatic fine quality rice in the world trade, popularly known as basmati, is traditionally grown in the north and north western part of Indian sub-continent (DRR, 1992). Nitrogen is one of the most important and effective elements required for obtaining high rice yields and
A field experiment was conducted during Kharif2018 at Research Farm, College of Agriculture, Central Agricultural University, Imphal, Manipur. The treatment consist of two methods of crop establishment viz. broadcasting and transplanting with five integrated nitrogen management viz. 100\% RDN through urea, 75\% RDN through urea + 25\% RDN through FYM, 50\% RDN through urea + 50\% RDN through FYM and $100 \%$ RDN through FYM and control. The results revealed that application of integrated nitrogen management at the rate of $75 \%$ RDN through urea $+25 \%$ RDN through FYM significantly influenced growth, yield attributes and yield over control. The highest grain yield $(2638 \mathrm{~kg}$ $\left.\mathrm{ha}^{-1}\right)$, straw yield $\left(6092 \mathrm{~kg} \mathrm{ha}^{-1}\right)$ and harvest index $(30.04 \%)$ were recorded from $75 \% \mathrm{RDN}$ through urea $+25 \%$ RDN through FYM. The highest gross return (Rs. 240267 ha $^{-1}$ ), net return (Rs.188997ha ${ }^{-1}$ ) and benefit cost ratio (3.69) were also obtained from the application of $75 \%$ RDN through urea $+25 \%$ RDN through FYM. stimulating a lot of vital processes in plants in agriculture (Niang et al., 2009). Excessive use of fertilizers will cause environmental pollution and will destroy the balance of the ecosystem that is one of the major problems (Zaller, 2007).

However, long term use of inorganic fertilizers deterioration of soil structure, soil health and environmental pollution (Singh, 
2000). Integration of organic manures with inorganic fertilizer is essential to maintain soil fertility and to balance nutrient supply in order to boost up the crop yield per unit area (Arif et al., 2014). Organic manures provide regulated supply of plant nutrients by slowly released resulted in increasing yield of rice and nitrogen use efficiency (Sharma et al., 2002). However, the use of organic manures alone might not meet the plant requirement due to presence of relatively low levels of nutrients. In order to make the soil well supplied with all the plant nutrients in the readily available form and to maintain good soil health, it is necessary to use organic manures in conjunction with inorganic fertilizers (Fageria et al., 2001).

Farmyard manure (FYM) is being used as organic manure in field crops as it supplies all essential plant nutrients and increases activities of microbes in soil (Sutaliya and Singh, 2005). The conjunctive application of organics with inorganic sources of nutrients reduces the dependence on chemical inputs and it not only acts as a source of nutrients but also provides micro nutrients as well as modifies the soil physical behaviour and increases the efficiency of applied nutrients (Parihar et al., 2010).

Farm yard manure (FYM) is the most effective measure for the improving soil fertility and thereby crop productivity (Hossaen et al., 2011). The integrated nitrogen management helps to maintain soil health and enhanced rice productivity. Application of urea in combination with organic material (FYM) minimizes $\mathrm{N}$ loss and increasing $\mathrm{N}$-use efficiency.

\section{Materials and Methods}

A field experiment was conducted during kharif 2018 to study the effect of different establishment techniques and integrated nitrogen management on basmati variety "Pusa Basmati 1509". The experimental soil was clay with $\mathrm{pH}$ 5.42. The soil was high in organic carbon $(1.09 \%)$ and medium in available nitrogen $\left(301 \mathrm{~kg} \mathrm{ha}^{-1}\right)$, and available potash $\left(225 \mathrm{~kg} \mathrm{ha}^{-1}\right)$ but low available phosphorous $\left(16 \mathrm{~kg} \mathrm{ha}^{-1}\right)$. The total rainfall received during the cropping season was 789 $\mathrm{mm}$.

The treatment consist of two crop establishment techniques viz., broadcasting and transplanting with five integrated nitrogen management viz. $100 \%$ RDN through urea, $75 \%$ RDN through urea $+25 \%$ RDN through FYM, 50\% RDN through urea + 50\% RDN through FYM and $100 \%$ RDN through FYM and control.

The experiment was replicated thrice in factorial randomised block design. Biometric observations on plant height, number of effective tillers $\mathrm{m}^{-2}$, panicle length, number of filled grains panicle ${ }^{-1}$, grain yield, straw yield and harvest index were recorded. The data were subjected to analysis of variance (ANOVA) with three replication in factorial randomised block design by using excel. The least significant difference (LSD) was calculated in comparing the treatment means at $5 \%$ level of probability.

\section{Results and Discussion}

\section{Effect of seedling establishment techniques}

\section{Growth and yield attributes}

Data in Table 1 shows that the highest plant height $(123.72 \mathrm{~cm})$ was recorded from transplanting which was significantly higher than broadcasting $(116.88 \mathrm{~cm})$. It might be due to more space, sunlight and nutrients available to wider spaced plants of transplanting than close spaced plants which facilitated the plants to attained more height. 
(Shriame et al., 2000) reported that the number of functional leaves and leaf area were higher under wider spacing, which increased the photosynthetic rate leading to taller plant. The highest number of effective tiller $\mathrm{m}^{-2}$ obtained from transplanting (254.67) was found to be significantly higher than broadcasting (220). Better growth of plants like of plant height and number of tiller $\mathrm{m}^{-2}$ produced transplanting rice significantly greater number of effective tillers $\mathrm{m}^{-2}$ than broadcasting (Gill and Walia, 2014).

Panicle length was not significantly influenced by different crop establishment techniques. But panicle length was higher in transplanting $(24.17 \mathrm{~cm})$ than the broadcasting $(23.68 \mathrm{~cm})$ (Jain et al., 2018) also reported that transplanting rice of panicle length was higher than broadcasting due to efficient nutrient uptake and good plant growth. Number of filled grains panicle ${ }^{-1}$ had significant effect with establishment techniques. Highest number of filled grains panicle $^{-1}$ (67.36) was recorded from transplanting than broadcasting (61.55). Transplanting rice had more light interception with proper spacing that enhanced to filled grains (Maqsood et al., 2013).

\section{Yield}

Seedling establishment through transplanting produced significantly higher grain yield (2246 kg ha ${ }^{-1}$ ) as compared to broadcasting (1689 kg ha $\left.{ }^{-1}\right)$. Highest grain yield in transplanting might be due to more number of effective tillers $\mathrm{m}^{-2}$, more number of filled grain panicle ${ }^{-1}$ and was also attributed to increase cumulative mean value of temperature and sunshine hour. Transplanting rice had a uniform spacing encouraged root system resulting in better nutrient uptake and efficient nutrient availability to the plant thereby, more easier in intercultural operations like weeding and spraying
(Srivastava et al., 2009). (Singh et al., 2001) while working at Faizabad obtained significantly higher yield of transplanted rice than direct broadcasting of pre-germinated seeds in loam soil due to significantly higher number of panicles $\mathrm{m}^{-2}$, grains panicle ${ }^{-1}$ and panicle length. (Sanjay et al., 2006) enumerated that grain yield of rice was significantly influenced by planting systems. Line transplanting system recorded significantly higher grain yield (55.3 $\left.\mathrm{q} \mathrm{ha}^{-1}\right)$ as compared to direct seeding using drum seeder $\left(54.3 \mathrm{q} \mathrm{ha}^{-1}\right)$.

Straw yield was significantly higher in transplanting (5847 $\mathrm{kg} \mathrm{ha}^{-1}$ ) as compared to broadcasting ( $5200 \mathrm{~kg} \mathrm{ha}^{-1}$ ). It might be due to increased number of tiller $\mathrm{m}^{-2}$ with moderate plant height and better performance of yield attributing ultimately led the increase the biomass in the transplanting method of rice establishment.

The lowest yield was recorded in broadcasting method might be due to lesser of effective tiller $\mathrm{m}^{-2}$ and increased inter and intra plant competition for available growth resources on account of weed infestation. However, (Sanjay et al., 2006) reported that direct seeding using drum seeder recorded significantly higher straw yield (73.7 $\mathrm{q} \mathrm{ha}^{-1}$ ) compared to line transplanting (69.9 $\left.\mathrm{q} \mathrm{ha}^{-1}\right)$ and broadcast sowing (55.4 $\left.\mathrm{q} \mathrm{ha}^{-1}\right)$.

Harvest index is the function of grain yield to the total biological yield (grain + straw). Harvest index was also influenced significantly by transplanting (26.88) than broadcasting (24.09). However, Dingkuhn et al., (2001) reported higher harvest index in transplanted crop over direct sown crop.

The lower harvest index in direct seeded rice indicated that the major proportion of its biomass was in terms of straw rather than the grain. 
Table.1 Effect of establishment techniques and integrated nitrogen management on growth, yield attributes and yield of rice variety 'Pusa Basmati 1509'

\begin{tabular}{|c|c|c|c|c|c|c|c|}
\hline Treatments & $\begin{array}{l}\text { Plant } \\
\text { height } \\
(\mathrm{cm})\end{array}$ & $\begin{array}{l}\text { No. of } \\
\text { effective } \\
\text { tillersm }\end{array}$ & $\begin{array}{c}\text { Panicle } \\
\text { length } \\
(\mathrm{cm})\end{array}$ & $\begin{array}{l}\text { No. of } \\
\text { filled } \\
\text { grains } \\
\text { panicle }^{-1}\end{array}$ & $\begin{array}{c}\text { Grain } \\
\text { yield } \\
\left(\mathrm{kg} \mathrm{ha}^{-1}\right)\end{array}$ & $\begin{array}{c}\text { Straw } \\
\text { yield } \\
\left(\mathrm{kg} \mathrm{ha}^{-1}\right)\end{array}$ & $\begin{array}{c}\text { Harvest } \\
\text { index } \\
(\%)\end{array}$ \\
\hline \multicolumn{8}{|l|}{ Establishment techniques (S) } \\
\hline Broadcasting $\left(\mathbf{S}_{1}\right)$ & 116.88 & 220.00 & 23.68 & 61.55 & 1689 & 5200 & 24.09 \\
\hline Transplanting $\left(\mathbf{S}_{2}\right)$ & 123.72 & 254.67 & 24.17 & 67.36 & 2246 & 5847 & 26.88 \\
\hline $\operatorname{SEm}( \pm)$ & 1.69 & 3.05 & 0.20 & 1.25 & 57.43 & 25.39 & 0.66 \\
\hline C.D. $(P=0.05)$ & 5.03 & 9.04 & NS & 3.73 & 170.55 & 75.41 & 1.97 \\
\hline \multicolumn{8}{|c|}{ Integrated nitrogen management $(\mathrm{N})$} \\
\hline $100 \%$ RDN through urea $\left(\mathrm{N}_{1}\right)$ & 124.57 & 247.17 & 25.23 & 70.60 & 2147 & 5958 & 26.30 \\
\hline $\begin{array}{l}75 \% \text { RDN through urea }+ \\
25 \% \text { RDN through FYM }\left(\mathrm{N}_{2}\right)\end{array}$ & 125.87 & 258.17 & 25.52 & 83.30 & 2638 & 6092 & 30.04 \\
\hline $\begin{array}{l}50 \% \text { RDN through urea }+ \\
50 \% \text { RDN through FYM }\left(\mathbf{N}_{3}\right)\end{array}$ & 121.00 & 245.33 & 24.82 & 65.17 & 2123 & 5611 & 27.23 \\
\hline $100 \%$ RDN through FYM $\left(\mathrm{N}_{4}\right)$ & 118.43 & 239.17 & 24.71 & 61.33 & 1987 & 5357 & 26.95 \\
\hline Control $\left(\mathbf{N}_{5}\right)$ & 111.63 & 196.83 & 19.33 & 41.87 & 941 & 4600 & 16.91 \\
\hline $\operatorname{SEm}( \pm)$ & 2.68 & 4.81 & 0.32 & 1.98 & 90.80 & 40.15 & 1.05 \\
\hline C.D. $(P=0.05)$ & 7.96 & 14.30 & 0.95 & 5.89 & 269.66 & 119.23 & 3.12 \\
\hline \multicolumn{8}{|l|}{ Interaction $(\mathbf{N} \times \mathbf{S})$} \\
\hline $\operatorname{SEm}( \pm)$ & 3.79 & 6.81 & 0.45 & 2.81 & 128.41 & 56.77 & 1.49 \\
\hline C.D. $(P=0.05)$ & NS & 20.22 & NS & NS & 381.36 & 168.61 & NS \\
\hline
\end{tabular}

Table.2 Effect of establishment techniques and integrated nitrogen management on economics

\begin{tabular}{|l|c|c|c|}
\hline Treatment & $\begin{array}{c}\text { Gross income } \\
\left(\text { Rs.ha }^{-1}\right)\end{array}$ & $\begin{array}{c}\text { Net income } \\
\left(\text { Rs.ha }^{-1}\right)\end{array}$ & B:C ratio \\
\hline $\mathbf{S}_{\mathbf{1}} \mathbf{N}_{\mathbf{1}}$ & 142773 & 97823 & 2.18 \\
\hline $\mathbf{S}_{\mathbf{1}} \mathbf{N}_{\mathbf{2}}$ & 181867 & 129747 & 2.49 \\
\hline $\mathbf{S}_{\mathbf{1}} \mathbf{N}_{\mathbf{3}}$ & 138667 & 79367 & 1.34 \\
\hline $\mathbf{S}_{\mathbf{1}} \mathbf{N}_{\mathbf{4}}$ & 136640 & 62990 & 0.86 \\
\hline $\mathbf{S}_{\mathbf{1}} \mathbf{N}_{\mathbf{5}}$ & 75627 & 36877 & 0.95 \\
\hline $\mathbf{S}_{\mathbf{2}} \mathbf{N}_{\mathbf{1}}$ & 200800 & 156700 & 3.55 \\
\hline $\mathbf{S}_{\mathbf{2}} \mathbf{N}_{\mathbf{2}}$ & 240267 & 188997 & 3.69 \\
\hline $\mathbf{S}_{\mathbf{2}} \mathbf{N}_{\mathbf{3}}$ & 201067 & 142617 & 2.44 \\
\hline $\mathbf{S}_{\mathbf{2}} \mathbf{N}_{\mathbf{4}}$ & 181333 & 108533 & 1.49 \\
\hline $\mathbf{S}_{\mathbf{2}} \mathbf{N}_{\mathbf{5}}$ & 74933 & 37033 & 0.98 \\
\hline
\end{tabular}




\section{Effect of integrated nitrogen management}

\section{Growth and yield attributes}

The maximum plant height $(125.87 \mathrm{~cm})$ was recorded with the application of $75 \%$ RDN through urea $+25 \%$ RDN through FYM and the lowest $(111.63 \mathrm{~cm})$ was observed from control. It was followed by $100 \% \mathrm{RDN}$ through urea and 50\% RDN through urea + $50 \%$ RDN through FYM. The increased in plant height might be due to adequate nutrient supply to the plant which resulted into rapid growth by good establishment of root and various metabolic process and ultimately performed better mobilization of synthesized carbohydrates in to amino acid and protein which stimulated the rapid cell division and cell elongation. Finally, it resulted in to growth of plant faster as compare to other treatments (Sujathamma and Reddy, 2004).

Yield attributing characters like number of effective tillers $\mathrm{m}^{-2}$ panicle length, number of filled grains panicle ${ }^{-1}$, grain yield, straw yield and harvest index were also significantly influenced by integrated nitrogen management. The highest number of effective tillers $\mathrm{m}^{-2}$ (258.17) was obtained with application of $75 \%$ RDN through urea $+25 \%$ RDN through FYM. The lowest number of effective tillers $\mathrm{m}^{-2}$ (196.83) was recorded from control. The results clearly indicated that the application of organic manures with chemical fertilizers increased effective tillers $\mathrm{m}^{-2}$ which was comparable to the $100 \%$ chemical fertilized treatment (Rahman et al., 2009). Interaction between the establishment techniques and integrated nitrogen management were significantly influenced on number of effective tillers $\mathrm{m}^{-2}$. The maximum number of effective tillers $\mathrm{m}^{-2}$ (260) was recorded from $\mathrm{S}_{2} \mathrm{~N}_{2}$ transplanting with $75 \%$ RDN through urea $+25 \%$ RDN through FYM whereas the minimum number of effective tillers $\mathrm{m}^{-2}$ (148.67) was observed from $\mathrm{S}_{1} \mathrm{~N}_{5}$ broadcasting at control. It might be due to integrated use of urea with FYM sources of fertilizers have enhanced the nitrogen availability then resulting increased nitrogen uptake by rice which promoted the production of more number of effective tillers (Imade et al., 2017). Panicle length of rice was significantly influenced by different treatments (Table 1). The highest panicle length $(25.52 \mathrm{~cm})$ was observed at $75 \%$ RDN through urea $+25 \%$ RDN through FYM treatment. The lowest panicle length (19.33) was observed at control. The result further showed that panicle length increase was directly influenced by the increased dose of organic manure in combination with chemical fertilizers. However, (Kumar and Singh, 2006) reported that the combined application of organic manure and chemical fertilizers increased panicle length of rice. The increase in panicle length may be due to application of organic and chemical fertilizers which resulted in more availability of macronutrients as well as micronutrients (Babu et al., 2001). The number of filled grains panicle ${ }^{-1}$ was significantly affected due to application of urea with FYM. The highest number of filled grains panicle ${ }^{-1}$ (83.30) was found at $75 \%$ RDN through urea $+25 \%$ RDN through FYM. The lowest number of filled grains panicle $^{-1}$ (41.87) was recorded from control. The combined application nitrogen with FYM sources of fertilizers was enhanced the nitrogen availability then resulting nutrient were utilized for grain formation and grain filling (Kumar et al., 2016).

The grain yield of basmati rice (cv. Pusa basmati 1509) responded significantly to integrated use of urea with FYM and results have been presented in the Table 1 . All the treatments produced significantly higher grain yield over control. The highest grain yield $\left(2638 \mathrm{~kg} \mathrm{ha}^{-1}\right)$ was obtained with application of $75 \%$ RDN through urea $+25 \%$ RDN through FYM. The lowest grain yield (941 
$\mathrm{kg} / \mathrm{ha}$ ) was observed from control. The study revealed that integrated use of cow dung and poultry manure with chemical fertilizers reduced fertilizer without any remarkable yield decline (Haque et al., 2001 and Rajni et al., 2001). However, (Mondal et al., 2003) also observed that the number of panicle $\mathrm{m}^{-2}$ and number of filled grains panicle ${ }^{-1}$ was highest with the application of $75 \%$ of the recommended dose of NPK $(60 \mathrm{~kg} \mathrm{~N}+30 \mathrm{~kg}$ $\left.\mathrm{P}_{2} \mathrm{O}_{5}+30 \mathrm{~kg} \mathrm{~K} 2 \mathrm{O}\right)$ along with FYM @ $4 \mathrm{tha}$ 1 . The maximum rice grain yield $\left(6 \mathrm{tha}^{-1}\right)$ was also recorded at $75 \%$ of the recommended dose of NPK+FYM @ $4 \mathrm{t} \mathrm{ha}^{-1}$. Interaction between the establishment techniques and integrated nitrogen management were significantly influenced on grain yield. Highest grain yield (3003 $\mathrm{kg} \mathrm{ha}^{-1}$ ) was recorded from the transplanting along with application of $75 \%$ RDN through urea $+25 \%$ RDN through FYM whereas the lowest grain yield (936.67 $\mathrm{kg} \mathrm{ha}^{-1}$ ) was observed from transplanting without any fertilizer (control). Application of organic manure in addition to the recommended dose of fertilizers produced significantly higher grain yield in rice (Rabeya Khanam et al., 1997). The increased grain yield was due to uptake of nutrients in paddy and the application of organic manure reduced the dosage of NPK. This may indicate that organic manure reduces the loss of nutrients through leaching from the soil (Bhattacharjee et al., 2001). The highest straw yield (6092 $\left.\mathrm{kg} \mathrm{ha}^{-1}\right)$ was recorded with application of $75 \%$ RDN through urea $+25 \%$ RDN through FYM. The lowest straw yield (4600 kg/ha) was observed from control. (Singh, 2001) also reported that the application of organic manure and chemical fertilizers increased straw yield. Interaction between the establishment techniques and integrated nitrogen management were significantly influenced on straw yield. The highest straw (6302 kg ha ${ }^{-1}$ ) was recorded from transplanting along with application of $75 \%$ RDN through urea $+25 \%$ RDN through
FYM whereas the lowest straw yield (44367 $\mathrm{kg} \mathrm{ha}^{-1}$ ) was observed broadcasting without any fertilizer. (Rahman et al., 2009) reported that the application of organic manure and chemical fertilizers increased the grain and straw yields of rice. The highest harvest index (30.04) was recorded with application of $75 \%$ RDN through urea $+25 \%$ RDN through FYM. The lowest harvest index (16.91) was observed at control. It might be due to better partitioning of photosynthetic substance to economic yield. Appreciably high harvest index shows the efficiency of converting biological yield into economic yield (Arif et $a l ., 2014)$. The increase in yield was further attributed to better translocation of photosynthates from source to sink due to higher uptake of NPK which are responsible for quick and easy translocation of photosynthates (Dongarwar et al., 2007).

\section{Economics}

Analysis of economics factors like gross return, net return, and benefit cost ratio are important to evaluate the effect of establishment techniques and integrated nitrogen management (Table 2). Grain yield was major factor which caused differences in net income and net return per rupees invested. Maximum Gross return (Rs.240267 ha ${ }^{-1}$ ), net return (Rs.188997 ha ${ }^{-1}$ ) and benefit cost ratio (3.69) were recorded from transplanting along with application of $75 \%$ RDN through urea + 25\% RDN through FYM. The lowest gross return (Rs.74933 $\mathrm{ha}^{-1}$ ) was recorded from transplanting without any fertilizer, the lowest net return (Rs.36877 ha-1) from broadcasting without any fertilizer and the lowest benefit cost ratio (0.86) was obtained from broadcasting without any fertilizer. It might be due to higher production of grain and straw yield and higher increased in output in comparison to input (Tomar et al., 2018). However, Sharma et al., (2018), Tripathi, V.K. and Mishra, H.C. (2012) also reported 
that the maximum gross income, net return and benefit cost ratio was recorded from the integrated (Fertilizer + FYM) treatment for basmati rice and the lowest from control.

\section{Acknowledgement}

The authors are thankful to the Dean, College of Agriculture, Central Agricultural University, Imphal for financial and technical support to carry out this research experiment.

\section{References}

Arif, M., Tasneem, M., Bashir, F., Yaseen, G. and Iqbal, R.M. (2014). Effect of integrated use of organic manures and inorganic fertilizers on yield and yield components of rice.J. Agric. Res., 52(2):197-206.

Babu, S., Marimuthu, R., Manivanna, V. and Kumar, S.R. 2001. Effect of organic and inorganic manures on growth and yield of rice. Agri. Sci. Dig., 21: 232-34.

Bhattacharjee, G., Chaudhuri, P.S., and Datta, M. 2001. Response of paddy (var. TRC87-251) crop on amendment of the field with different levels of vermicompost. Asian J. Microbiol. Biotechnol. Environ. Sci., 3: 191-196.

Dingkuhn, M., Gruz, R. J., Toole, J. C., Turner, C. and Dorffling, K. 2001. Responses of seven diverse rice cultivars to water deficit III. Accumulation of Abscissic acid and proline in relation to leaf water potential and osmotic adjustment.Field crop Res., 27: $103-117$.

Dongarwar, U.R., Bhalerao, P.D., Negduie, S.J. 2007. Effect of irrigation and INM on growth and yield of Indian mustard. Ann.physio., 21(2):182-185.

DRR, (Directorate of Rice Research) (1992).Basmati rice, Hyderabad, DRR. 4-18.

Fageria, N.K. and Barbosa, F. (2001).
Nitrogen use efficiency in lowland rice genotypes. Commun. soil sci. and plant anal., 32: 2079-2089.

Gill, J.S. and Walia, S.S. (2014). Effect of establishment methods and nitrogen levels on basmati rice (Oryza sativa L.). Indian J. Agron., 58: 506-511.

Haque, M.Q., Rahman, M.H., Rijpma, F. J. and Kadir, M.M. (2001). Integrated nutrient management in relation to soil fertility and yield sustainability under Wheat-Mung-T. Aman cropping pattern. Online J. Biol. Sci., 1(8):73 1734.

Hossaen, M.A., Shamsuddoha, A.T.M., Paul, A.K., Bhuiyan, M.S.I. and Zaheer. (2011). Efficacy of different organic manures and inorganic fertilizer on the yield and yield attributes of Boro rice. The Agriculturists, 9(2):117-125.

Imade, S.R., Thanki, J.D., Phajage, S.K. and Nandapure, S.P. (2017). Effect of integrated nutrient management on growth, yield and quality of rice. Bull. Env. Pharmacol. Life Sci., 6(3): 352355.

Jain, B.T., Sarial, A.K. and Kesh, H. (2018).Comparison of Yield Potential of Basmati Rice (Oryza sativa) through Direct Seeded Rice, SRI and Conventional Technology. Res. J. Agric. Sci., 9(2): 300-306.

Kumar, R., Zaidi, S.F.A., Singh, G., Kumar, B. and Nishad, K.K. (2016). Effect of integrated nutrient management on yield and phosphorus availability of aromatic rice (Oryza sativa L.) in inceptisol of eastern U. P. Adv. Res. J. Crop Improv., 7(1):145-147.

Kumar, V. and Singh, O.P. (2006). Effect of organic manures Nitrogen and Zinc fertilization on growth, yield, yield attributes and quality of rice (Oryza sativa L). J. Plant Sci., 1(2): 311-314.

Maqsood, M., Asif, M.S., Syed, N., Azam, A. and Iqbal, M. (2013). Rice cultures and 
nitrogen rate effects on yield and quality of rice (Oryza sativa L.)Turk J. Agric., 37: 665-673.

Mondal, S.S., Sarkar, S., Ghosh, A and Das, J. (2003). Response of summer rice (Oryza sativa L.) to different organic and inorganic sources of nutrients. Crop Res., 25: 219-222.

Niang, H.F., Liu, Z.H., Wang, Q.S., Lin, Z.M., Chen, S.J., Li, G.H., Wang, S.H. and Ding, Y.F. (2009). Effect of nitrogen fertilizer application on grain phytic acid and protein concentrations in japonica rice and its variations with genotypes. J. cereal Sci., 50(1): 49-55.

Parihar, C.M., Rana, K.S., and Kantwa, S.R., (2010). Nutrient management in pearl millet (Pennisetum glaucum)-mustard (Brassica juncea) cropping system as affected by land configuration under limited irrigation. Indian J. Agron., 55:191-196.

RabeyaKhanam, Sahu, S.K., and Mitra, G.N (1997). Yield maximization of rice through integrated Nutrient management on Aeric Ustochrept. $J$. Indian Society of Soil Sci., 45(2):96397.

Rahman, F., SakhawatHossain, A.T.M., Saha P.K. and MazidMiah, M.A. (2009). Effect of integrated use of organic manures and chemical fertilizers on yield, nutrient uptake and nutrient balance in the bush bean- T.AUS -T. Aman cropping pattern. Bangladesh $J$. Agril. Res., 34(1):157-164.

Rahman, M.S., Islam, M.R., Rahman, M.M. and Hossain, M.I. (2009). Effect of cowdung, poultry manure and urea-N on the yield and nutrient uptake of BRRI dhan 29. Bangladesh Res. Publ. J., 2: 552-558.

Rajni, R., Srivastava, O. P. and Rani, R. (2001). Effect of integration of organics with fertilizer $\mathrm{N}$ on rice and $\mathrm{N}$ uptake. Fert. News., 46(9): 63-65.
Sanjay, M.T., Prabhakara, T.K and Nanjappa, H.V. (2006). Enhancing productivity of rice (Oryza sativa L.) under different crop establishment methods through weed management practices. Crop Res., 31: 192-197.

Sharma, A.K., Singh, T., Patel, A. and Yadav, R.A. (2018). Influence of integrated nutrient management practices on scented rice (Oryza sativa L.) pertaining to eastern Uttar Pradesh. J. Pharmacogn. Phytochem, 7(5):14481453.

Sharma, S.P., Subehia, S.K., and Sharma, P.K. (2002). Long term effects of chemical fertilizers on soil quality, crop productivity and sustainability. Res. Bull. CSK Himachal Pradesh K.V.V., Palampur.

Shrirame, M.D., Rajgire, H.J. (2000). Effect of spacing and seedling number per hill on growth attributes and yield of rice hybrid under low land condition. J. Soil Crop. 10(1): 109-113.

Singh, G., Singh, O.P. and Yadav, R.A. (2001). Effect of methods of establishment and nitrogen application on yield and yield attributes of rice. Oryza, 27: 210-213.

Singh, R.B. (2000). Environmental consequences of agricultural development: a case study for the green revolution state of Haryana, India. Agr.Ecosys.Environ., 82: 97-103.

Srivastava, P., Srivastava, P.C., Singh, U.S. and Shrivastava, M. (2009). Effect of integrated and balanced nutrient application on soil fertility, yield and quality of Basmati rice. Arch. Agron. Soil Sci., 55(3):265-284.

Sujathamma, P. and Reddy, S.D. (2004). Growth, yield and nitrogen uptake of low land rice as influenced by integrated nutrient management. Indian J. Agri. Res., 38:268-272.

Sutaliya, R. and Singh, R.N. (2005). Effect of 
planting time, fertility level and phosphate- solubilizing bacteria on growth, yield and yield attributes of winter maize (Zea mays) under rice (Oryza sativa) - maize cropping system. Indian J.Agron., 50(3):173-75.

Tomar, R., Singh, N.B., Singh, V. and Kumar, D. (2018).Effect of planting methods and integrated nutrient management on growth parameters, yield and economics of rice. J. Pharmacogn. Phytochem., 7(2): 520-527.

Tripathi, V.K. and Mishra, H.C. (2012).
Impact of integrated nutrient management on yield, economics and soil fertility in hybrid rice (Oryza sativa) - mustard (Brassica juncea) cropping system. New agriculturist; 23(1):21-26.

Zaller, J.G. (2007). Vermicompost as a substitute for peat in potting media Effects on germination, biomass allocation, yields and fruit quality of three tomato varieties. Sci. Horti., 112:191-199.

\section{How to cite this article:}

Nurina Shahni, K. Nandini Devi, Mary Chongtham, Herojit Singh Athokpam and Gopimohan Singh, N. 2019. Studies on Different Crop Establishment Techniques and Nitrogen Management on Basmati Rice Variety (Pusa basmati 1509). Int.J.Curr.Microbiol.App.Sci. 8(06): 2423-2429. doi: https://doi.org/10.20546/ijcmas.2019.806.289 